\title{
Bacterial Meningitis among Adult Patients at University of Gondar Comprehensive Specialized Referral Hospital: Prevalence and Antimicrobial Susceptibility Patterns
}

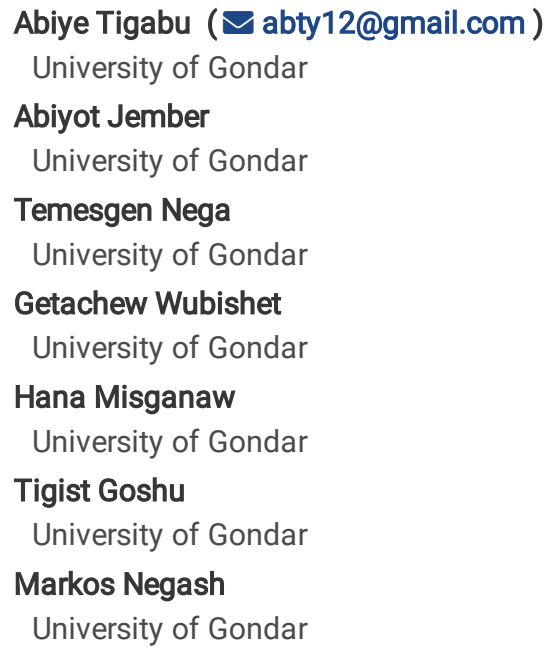

\section{Research}

Keywords: Bacterial meningitis, Adult patients, Antimicrobial susceptibility pattern, Gondar

Posted Date: November 17th, 2020

DOI: https://doi.org/10.21203/rs.3.rs-103544/v1

License: (c) (1) This work is licensed under a Creative Commons Attribution 4.0 International License. Read Full License 


\section{Abstract}

Background: Bacterial meningitis is a bacterial infection that causes inflammation of the membranes that surround the brain and spinal cord. The most frequent causes of bacterial meningitis are N. meningitidis, Streptococcus pneumonia, Listeria monocytogenes, and Homophiles influenza. This study aimed to determine bacterial meningitis and their antibiotic susceptibility patterns among adult patients.

Methods: A retrospective cross-sectional study was conducted on 3,683 patients to determine bacterial meningitis and their antibiotic susceptibility patterns from 2011 to 2020 . Cerebrospinal fluid samples were collected and inoculated on blood and chocolate agar plates, and then incubated at $37^{\circ} \mathrm{C}$ for 24 hours. Bacterial identification performed using morphological characters, gram stain, and standardized biochemical tests. Records of 3,683 culture results were collected and reviewed using a checklist from the registration book. Finally, data was entered, cleared, and checked using Epi-info version 7 and exported to SPSS version 20 for analysis. Logistic regression used for statistical association. The results were displayed using tables and figures. P-value $\leq 0.05$ at $95 \% \mathrm{Cl}$ was considered as statistically significant.

Results: Of the 3,683 patients, the overall prevalence of bacterial meningitis was $1.28 \%(47 / 3683)$. Of them, bacterial meningitis in males was $0.9 \%$ (33/3683) whereas, it was $0.38 \%$ (14/3683) in females. Bacterial meningitis among inpatients, 1.16\% (43/3683) was higher than their outpatient counterparts, $0.12 \%$ (4/3683). Ceftriaxone, chloramphenicol, ciprofloxacin, vancomycin, clindamycin, and erythromycin were the most effective antibiotics whereas penicillin, tetracycline, and cotrimoxazole were the least effective antibiotics for isolates. Being male in sex $(P=$ $0.048, \mathrm{AOR}=0.53, \mathrm{Cl}=0.283-0.993)$ was significantly associated with bacterial meningitis.

Conclusions: The prevalence of bacterial meningitis among adult patients was $1.28 \%$, which is considerably high. Being male in gender is a risk factor for bacterial meningitis. Therefore, infection preventive measures are required with a particular focus on adult patients. Further research is needed to explore the epidemiology and risk factors of meningitis.

\section{Background}

Meningitis is an infection caused by bacterial, viral, fungal, or protozoan agents that causes inflammation of membranes that surrounds the brain and spinal cord (meninges). Bacteria and viruses are the most common causes of meningitis. But bacterial meningitis (BM) is usually severe and common [1]. The most common etiologic agents of BM are E. coli, H. influenza, N. meningitidis, S. pneumonia, and L.

monocytogenes [2]. The classic symptoms of BM are fever, neck stiffness, altered mental status, and headache [3]. But the classical signs of $\mathrm{BM}$ are not always present in adults, and we cannot rule out based on the classical signs and symptoms alone [4,5]. BM is a severe infectious disease of the membranes lining the brain resulting in high mortality and morbidity throughout the world [6]. So, accurate and timely identification of the etiological agents is vital to initiate public health measures and ensure appropriate management [7].

Bacterial meningitis remains a common disease worldwide. The incidence of BM is between 3 and 5 per 100,000 people per year, and more than 2,000 deaths are reported annually in the United States [8]. The incidence of BM is a significant burden in adults with a mortality rate of up to $30 \%$ [9], and it requires prompt recognition and treatment [10]. S. pneumonia, $H$. influenza, and $N$. meningitidis have been responsible for $118.400,83.000$, and 75.000 deaths, respectively [12]. N. meningitidis was accountable for the large majority of BM epidemics in the meningitis belt of Sub-Saharan Africa [6, 11] and developing countries. S. pneumonia becomes a leading cause of meningitis among adults [12]. Adult BM is caused by $P$. aeruginosa, which usually found in the hospital area and patients with a post neurosurgical state [13]. The introduction of vaccines has reduced the burden of the two most common etiological agents for BM in adults such as S. pneumoniae and $N$. meningitidis [14].

Microbiological laboratory examination of cerebrospinal fluid (CSF) is the most definitive investigation for BM and guides possible choice of antibiotics and duration of therapy like third-generation cephalosporin is the initial antibiotics of choice in the absence of penicillin allergy and bacterial resistance. Amoxicillin is used if Listeria monocytogenes suspected in adults [15]. Besides, mass vaccinations can lead to herd immunity resulting in a dramatic reduction in infection rates among populations at risk [16]. Therefore, this study aimed to determine the prevalence and antimicrobial susceptibility patterns of bacterial meningitis among patients at the University of Gondar comprehensive specialized hospital.

\section{Methods}

\section{Study area}

The study was conducted at University of Gondar comprehensive specialized referral hospital, which serves more than five million people in Gondar town and the surrounding area. The town has 8 health centers, 21 private clinics, and one referral hospital which has more than 500 beds that provides health services such as surgery, internal medicine, pathology, TB/HIV, dermatology, antenatal care, delivery, postnatal care, laboratory, pharmacy, maternal and neonatal care, and other services for the population of Gondar town and surrounding areas.

\section{Study design, period and data collection}


A retrospective cross-sectional study was conducted to determine the prevalence and antimicrobial susceptibility patterns of bacterial meningitis among patients at University of Gondar compressive specialized hospital from 2011 to 2020 . Records of 3683 patients were collected and reviewed using a checklist from the registration book at medical bacteriology unit. Information concerning bacterial meningitis test results, age, sex, and type of patient visit (Inpatient or outpatient) of patients recorded from 2011 to 2020 in the registration book was collected using a data collection format.

\section{Laboratory inoculation and identification}

Each cerebrospinal fluid samples were inoculated onto blood and chocolate agar plates and incubated aerobically at $37^{\circ} \mathrm{C}$ for 24 hours. Samples that were culture positive on blood and chocolate agar plates, and the isolates obtained were identified using standard microbiological methods including colony morphology, Gram's stain reaction, and standardized biochemical tests such as indole production, lactose fermentation, hydrolysis of urea, citrate utilization, lysine decarboxylation, motility test, mannitol fermentation, catalase, and coagulase tests. A suspension of a pure colony from each confirmed culture isolate was performed by using $0.85 \%$ sterile normal saline for antimicrobial susceptibility testing and adjusted at 0.5 MacFarland standard. Using a sterile cotton tip applicator stick, the suspension was distributed evenly on Muller-Hinton agar, and a modified Kirby-Bauer disk diffusion technique implemented for antibiotic susceptibility pattern using different antibiotics.

\section{Data management and statistical analysis}

The quality of data was assured using a structured data collection format, asking laboratory staff how data registered including abbreviations in the laboratory and cross-checking by members of the data collector. Then data entered in statistical package EP-Info version 7, and data cleaned and analyzed using the statistical package SPSS version 20. Frequency distribution, percentages, and summary statistics were used to describe the study population concerning relevant variables. Odds Ratio (OR) was computed to assess statistical association, and the significance of statistical association was assured using p-value $<0.05$ at $95 \%$ confidence interval $(\mathrm{Cl})$.

\section{Results}

\section{Socio-demographic characteristics of study participants}

In this study, a total of 3683 adult patients greater than 18 years of age were included at University of Gondar teaching hospital during the study period. Out of these, $55.7 \%$ (2052/3683) were males, and $44.3 \%(1631 / 3683)$ were females. The mean age of the study participants was 36.115 years with a SD of \pm 14.41 with an age range of $18-97$ years. The majority of the study participants, $32.6 \%$ (1199/3683), belonged to $18-27$ years of age, while $29 \%$ (1067/3683) of patients belong to $28-37$ years of age. The majority, $90 \%(3313 / 3683)$ of patients were from inpatient visits while the rest, $10 \%$ (370/3683) of them were from outpatient departments. The majority, 32.27\% (1069/3313) of the inpatients are belong $18-27$ years of age, followed by $28-37$ years of age $32.2 \%$ (1067/3313) and 55.45\% (1837/3313) of the inpatients are males. In this study, cerebrospinal fluid samples collected by lumbar puncture, and the most frequently observed patient's age was 30 followed by 40 . Most of the study participants were involved in 2018 and 2014, 13.9\% (512/3683), and 11.5\% (425/3683), respectively. The age and sex distribution of patients involved in this study are presented (Table 1).

\section{Prevalence of bacterial meningitis and risk factors}

A total of 3,683 cerebrospinal fluid samples analyzed, the prevalence of bacterial meningitis among adult patients greater than 18 years was $1.28 \%$ (47/3683), and 12 different types of bacterial species were isolated. Of these, Streptococcus pneumonia (0.4\%, 15/3683) was the commonest isolated bacteria followed by Staphylococcus aureus, $(0.2 \%, 6 / 3683)$, Escherichia coli, $(0.2 \%, 6 / 3683)$, and $N$. meningitidis, $(0.1 \%$, $5 / 3683$ ) (Figure 1). The prevalence of bacterial meningitis among adult patients of different age category showed $12(0.33 \%), 18(0.49 \%), 9$ $(0.24 \%), 4(0.11 \%), 3(0.08 \%)$ and $1(0.03 \%)$ among the age groups $18-27$ years, $28-37$ years, 38-47 years, $48-57$ years, $58-67$ years and $\geq 67$ years, respectively. The proportion of bacterial meningitis among male patients was $0.896 \%(33 / 3683)$, but $0.38 \%$ (14/3683) among females. Bacterial meningitis among inpatients, 1.16\% (43/3683) were higher than their outpatient counterparts, 0.12\% (4/3683). Maximum bacterial isolates were found in 2019, 0.27\% (10/3683) followed by 2011, \% (7/3683), 2015, \% (7/3683) and 2012, \% (6/3683). Maximum bacterial isolates were found at age of 32 and $40,5(0.14 \%)$ and $4(0.11 \%)$, respectively. Being male in gender $(P=0.048 ; A O R=0.530 ; C l=0.283-0.993)$ was significantly associated with bacterial meningitis in adult patients. However, age $(P=0.916 ; A O R=1.011 ; C l=0.822-1.244)$ and patient visits (inpatients and outpatient visits) $(P=0.725 ; A O R=0.831 ; C l=0.297-2.329)$ were not significantly associated with bacterial meningitis.

\section{Trends ofbacterial meningitis}

Over the ten years study periods, the prevalence of bacterial meningitis was higher in $2019(0.272 \%, 10 / 3683), 2015(0.19 \%, 7 / 3683), 2011$ $(0.19 \%, 7 / 3683)$ and $2012(0.163 \%, 6 / 3683)$, while lower in $2013(0.082 \%, 3 / 3683), 2014(0.082 \%, 3 / 3683), 2016(0.082 \%, 3 / 3683), 2017$ (0.082\%, 3/3683), 2018 (0.054\%, 2/3683), and 2020(0.054\%, 2/3683) (Figure 2). 
Bacterial antimicrobial susceptibility tests done for bacterial isolates, and it shows that among 47 isolates tested for different antimicrobials; $S$. pneumonia isolates were sensitive for ampicillin $(100 \%, 6 / 6)$, ceftriaxone $(100 \%, 6 / 6)$, chloramphenicol $(77.8 \% 7 / 9)$, ciprofloxacin $(83.3 \%, 5 / 6)$, penicillin $(100 \%, 11 / 11)$, vancomycin $(87.5 \%, 7 / 8)$, erythromycin $(80 \%, 4 / 5)$ and tetracycline $(43 \%, 3 / 7)$. However, four $S$. pneumonia isolates were resistant to cotrimoxazole $(66.8 \%, 4 / 6)$. S. aureus isolates were sensitive for cefoxitin $(100 \%, 3 / 3)$, clindamycin $(100 \%, 3 / 3)$, erythromycin $(66.8 \%, 4 / 6)$, and amoxicillin $(66.8 \%, 2 / 3)$ (Table 2$)$. On the other hand, $E$. coli isolates were sensitive for ciprofloxacin $(60 \%, 3 / 5)$, gentamycin $(66.8 \%, 4 / 6)$. But five $E$. coli isolates were resistant to ampicillin $(100 \%, 5 / 5)$. And three $N$. meningitidis isolates were sensitive for amoxicillin $(100 \%, 3 / 3)$ and erythromycin $(100 \%, 3 / 3)$. But, three $N$. meningitidis isolates resistant to penicillin $(100 \%, 3 / 3)$, and two $K$. pneumonia isolates were sensitive for ceftazidime $(100 \%, 2 / 2)$ (Table 3$)$.

\section{Discussion}

Bacterial meningitis, a life-threatening worldwide disease, has to be reviewed periodically because the specific microorganisms responsible for the infection vary with time, geography, and patient age. It has become a disease of adults with a significant mortality rate that ranges from $20-$ $30 \%$. We performed this study to summarize prevalence figures obtained from CSF samples, with an exclusive focus on adults. The overall prevalence of bacterial meningitis among adult patients in this study is $1.28 \%$, which is higher than a study carried in Indonesia (0.68\%) [17]. However, it is lower than reported in Ethiopia (6.9\%) [18], Malawi (5.25\%) [19], South African (10.7\%) [20], Kenya (11.2\%) [21], Netherlands (13\%) [22], Yemen (52.7\%) [23] and Qatar (53.6\%) [24], which differs noticeably among studies, might be due to differences in characteristics and geographical distribution of the study population, sample size, diagnostic techniques, and differences in infection control policies. We noticed a significant prevalence of bacterial meningitis among adult patients, which indicates adults remain the population where the diseases meningitis prevalent and strict prevention strategies are required.

The present study showed that Streptococcus pneumonia, Staphylococcus aureus, Escherichia coli, and N. meningitidis were the predominant pathogens that caused bacterial meningitis. S. pneumoniae was the predominant pathogen, and it remains an important cause of bacterial meningitis, which is in agreement with the results of a previous study by Amaya-Villar $R$ et al [25], Van de Beek D et al [26], Wall EC et al [27], Mook-Kanamori BB et al [28], Adriani KS et al [29], Weisfelt $\mathrm{M}$ et al [30], and Mirecka A [31]. However, other studies reported that N. meningitidis (18), Mycobacterium tuberculosis [20], coagulase-negative staphylococci [24], and Listeria monocytogenes [32] were the leading cause of bacterial meningitis. Moreover, Staphylococcus aureus and Escherichia coli were the second frequent etiological agent, which is comparable with a study conducted by Mook-Kanamori BB et al (28) and Mirecka A [31].

The trends of bacterial meningitis among adult patients tend to decrease in $2013(0.08 \%), 2014(0.08 \%), 2016(0.08 \%), 2017(0.08 \%), 2018$ $(0.05 \%)$, and $2020(0.05 \%)$. However, the prevalence of bacterial meningitis significantly increased in $2011(0.22 \%), 2012(0.16 \%), 2015(0.19 \%)$, and $2019(0.27 \%)$. The highest prevalence of bacterial meningitis was observed in $2019(0.27 \%)$, and the lowest prevalence of bacterial meningitis was observed in $2018(0.05 \%)$ and $2020(0.05 \%)$. The prevalence of bacterial meningitis was not constantly decreased or increased in this study, However, differs noticeably between years, which might be due to the difference in the management of the disease, the prevention and infection control policies from year to year.

In this study, the majority of the isolated $S$. pneumonia were sensitive to ampicillin (100\%), ceftriaxone (100\%), chloramphenicol (77.8\%), ciprofloxacin (83.3\%), penicillin G $(100 \%)$, vancomycin $(87.5 \%)$, and erythromycin $(80 \%)$. This finding was in agreement with studies conducted by Purwanto DS et al [17] and by Gudina EK et al [33]. However, a study by Assegu Fenta D et al [18] and Khan FY et al [24] reported that $S$. pneumoniae was resistant to ceftriaxone and penicillin. S. aureus isolates were sensitive for cefoxitin (100\%), clindamycin (100\%), erythromycin $(66.8 \%)$, and amoxicillin (66.8\%). However, a study conducted by Assegu Fenta D et al [18] reported that $S$. aureus isolates were found to be (100\%) resistant to amoxicillin. On the other hand, E. coli isolates were sensitive for ciprofloxacin (60\%) but resistant for ampicillin (100\%) which is comparable with a study conducted by Gordon SB et al [19]. Furthermore, $N$. meningitidis isolates were sensitive for amoxicillin (100\%), and erythromycin (100\%), but resistant for penicillin (100\%). However, Mirecka A [31] reported that Neisseria meningitidis isolates were sensitive to penicillin. The differences in the susceptibility pattern of the isolates might be due to the differences in the management of antibiotics and diagnostic techniques employed.

Even if there are several factors considered as a risk factors for bacterial meningitis, and we found that being male in gender is significantly associated with bacterial meningitis in adult patients. The proportion of bacterial meningitis among male patients was higher than females. Male patients were 0.53 times more at risk of acquiring the disease meningitis as compared with female patients. This higher prevalence in males might be due to males more exposed to smoking, alcohol drinking and HIV infection which makes them more vulnerable to bacterial infection. In this study, age is not is not significantly associated with meningitis $(p>0.05)$. However, a study by Abdulrab A et al [23], AmayaVillar R et al [25], and Van de Beek D et al [26] reported that age was independently associated with bacterial meningitis. Bacterial meningitis among inpatients were higher than their outpatient counterparts. But being inpatient in a hospital is not significantly associated with bacterial meningitis $(p>0.05)$. 


\section{Conclusions And Recommendations}

In conclusion, the prevalence of bacterial meningitis among adult patients was $1.28 \%$, which is considerably high. Being male in gender is a risk factor for bacterial meningitis. Therefore, infection preventive measures are required with a particular focus on adult patients. Further research is needed to explore the epidemiology and risk factors of meningitis.

\section{Abbreviations}

BM-Bacterial Meningitis, CSF-Cerebrospinal Fluid, Cl-Confidence Interval, OR-Odds Ratio

\section{Declarations}

\section{Ethical approval and consent to participate}

Ethical approval was obtained from the University of Gondar ethical review committee. A legal permission and support letter was obtained from College of Medicine and Health Sciences hospital director office. The objectives of the study were explained to the heads of the hospital director and health care providers who worked at medical microbiology department and clarification was given before starting data collection from the registrations and client cards. To ensure confidentiality of information from participant's records, no personal identifiers were recorded in the client information extraction pre-designed form, and data secured from participant records were not available to anyone except for the main investigator.

\section{Consent for publication}

Not applicable

\section{Availability of data and materials}

All data generated or analyzed during this study were included in this article. Data that support the findings of this study are also available from the corresponding author upon reasonable request.

\section{Competing interest}

We declare that we have no competing interests.

\section{Funding}

There was no funding for this research.

\section{Authors' contribution}

All authors contributed equally to the conception, drafting, study design, execution, acquisition, analysis, and interpretation of data, write up and critically reviewing of the manuscript; gave final approval of the version to be published; have agreed on the journal to which the article has been submitted; and agree to be accountable for all aspects of the work.

\section{Acknowledgements}

We would like to thank all participants of this research, University of Gondar Hospital, the staff of Medical Microbiology, School of Biomedical and Laboratory Science, College of Medicine and Health Sciences for their contribution to the maturation and the success of this research.

\section{References}

1. Rashid LR. Clinical Manifestations of Bacterial Meningitis. 2018.

2. Domingo P, Pomar V, Benito N, Coll P. The changing pattern of bacterial meningitis in adult patients at a large tertiary university hospital in Barcelona, Spain (1982-2010). Journal of Infection. 2013; 66(2):147-54

3. Lin AL, Safdieh JE. The evaluation and management of bacterial meningitis: current practice and emerging developments. The neurologist. 2010 May $1 ; 16(3): 143-51$.

4. van de Beek D, Brouwer MC, de Gans J, Verstegen MJ, Spanjaard L, Pajkrt D. Richtlijn bacterial meningitis. Utrecht: Nederlandse Vereniging voor Neurologie. 2013. 
5. Van de Beek D, Cabellos C, Dzupova O, Esposito S, Klein M, Kloek AT, et al. ESCMID guideline: diagnosis and treatment of acute bacterial meningitis. Clinical microbiology and infection. 2016 May 1; 22:S37-62.

6. Jafri RZ, Ali A, Messonnier NE, Tevi-Benissan C, Durrheim D, Eskola J, et al. Global epidemiology of invasive meningococcal disease. Population health metrics. 2013 Dec 1; 11(1):17.

7. Greenhow TL, Hung Y-Y, Herz AM, Losada E, Pantell RH. The changing epidemiology of serious bacterial infections in young infants. The Pediatric infectious disease journal. 2014; 33(6):595-9.

8. Nur HE, Jamaiah I, Rohela M, Nissapatorn V. Bacterial meningitis: A five year (2001-2005) retrospective study at university Malaya medical center (UMMC), Kuala Lumpur, Malaysia. 2008.

9. McGill F, Heyderman RS, Panagiotou S, Tunkel AR, Solomon T. Acute bacterial meningitis in adults. The Lancet. 2016 Dec 17; 388(10063):3036-47.

10. Lukšić I, Mulić R, Falconer R, Orban M, Sidhu S, Rudan I. Estimating global and regional morbidity from acute bacterial meningitis in children: assessment of the evidence. Croatian medical journal. 2013 Dec 15; 54(6):510-8.

11. Mohammed I, Iliyasu G, Habib AG. Emergence and control of epidemic meningococcal meningitis in sub-Saharan Africa. Pathogens and global health. 2017; 111(1):1-6.

12. Veltman JA, Bristow CC, Klausner JD. Meningitis in HIV-positive patients in sub-Saharan Africa: a review. Journal of the International AIDS Society. 2014 Jan; 17(1):19184.

13. Pai S, Bedford L, Ruramayi R, Aliyu SH, Sule J, Maslin D, Enoch DA. Pseudomonas aeruginosa meningitis/ventriculitis in a UK tertiary referral hospital. QJM: An International Journal of Medicine. 2015 May 18; 109(2):85-9.

14. Van Ettekoven CN, van de Beek D, Brouwer MC. Update on community-acquired bacterial meningitis: guidance and challenges. Clin Microbiol Infect. 2017; 23(9):601-6.

15. Chaudhuri A, Martin P, Kennedy P, Andrew Seaton R, Portegies P, Bojar M, et al. EFNS guideline on the management of community-acquired bacterial meningitis: report of an EFNS Task Force on acute bacterial meningitis in older children and adults. European journal of neurology. 2008; 15(7):649-59.

16. Rashid H, Khandaker G, Booy R. Vaccination and herd immunity: what more do we know?. Current opinion in infectious diseases. 2012 Jun $1 ; 25(3): 243-9$.

17. Purwanto DS, Loho T, Tafroji W, Mangunatmadja I, Immanuel S, Timan IS, et al. Isolation and identification of Streptococcus pneumoniae serotype 6B from a patient with bacterial meningitis infection in Jakarta, Indonesia. Access Microbiology. 2020 Mar 26:acmi000123.

18. Assegu Fenta D, Lemma K, Tadele H, Tilahun BT, Derese B. Antimicrobial sensitivity profile and bacterial isolates among suspected pyogenic meningitis patients attending at Hawassa University Hospital: Cross-sectional study. BMC Microbiology. 2020 Dec; 20:1-10.

19. Gordon SB, Walsh AL, Chaponda M, Gordon MA, Soko D, Mbwvinji M, et al. Bacterial meningitis in Malawian adults: pneumococcal disease is common, severe, and seasonal. Clinical Infectious Diseases. $2000 \mathrm{Jul}$ 1; 31(1):53-57.

20. Britz E, Perovic O, Von Mollendorf C, Von Gottberg A, lyaloo S, Quan V, et al. The epidemiology of meningitis among adults in a South African province with a high HIV prevalence, 2009-2012. PloS one. 2016 Sep 26; 11(9):e0163036.

21. Gituro CN, Nyerere A, Ngayo MO, Maina E, Githuku J, Boru W. Etiology of bacterial meningitis: a cross-sectional study among patients admitted in a semi-urban hospital in Nairobi, Kenya. The Pan African Medical Journal. 2017; 28(Suppl 1).

22. Van Veen KE, Brouwer MC, Van Der Ende A, Van De Beek D. Bacterial meningitis in diabetes patients: a population-based prospective study. Scientific reports. 2016 Nov 15; 6(1):1-7.

23. Abdulrab A, Algobaty F, Salem AK, Mohammed YA. Acute bacterial meningitis in adults: a hospital based study in Yemen. Japanese journal of infectious diseases. 2010 Mar 1; 63(2):128-131.

24. Khan FY, Abu-Khattab M, Almaslamani EA, Hassan AA, Mohamed SF, Elbuzdi AA, et al. Acute bacterial meningitis in Qatar: a hospital-based study from 2009 to 2013. BioMed research international. 2017 Jan 1; 2017.

25. Amaya-Villar R, García-Cabrera E, Sulleiro-Igual E, Fernández-Viladrich P, Fontanals-Aymerich D, Catalán-Alonso P, et al. Three-year multicenter surveillance of community-acquired Listeria monocytogenes meningitis in adults. BMC Infectious Diseases. 2010 Dec 1 ; 10(1):324.

26. Van de Beek D, De Gans J, Spanjaard L, Weisfelt M, Reitsma JB, Vermeulen M. Clinical features and prognostic factors in adults with bacterial meningitis. New England Journal of Medicine. 2004 Oct 28; 351(18):1849-1859.

27. Wall EC, Everett DB, Mukaka M, Bar-Zeev N, Feasey N, Jahn A, et al. Bacterial meningitis in Malawian adults, adolescents, and children during the era of antiretroviral scale-up and Haemophilus influenzae type b vaccination, 2000-2012. Clinical Infectious Diseases. 2014 May 15; 58(10):e137-1345.

28. Mook-Kanamori BB, Fritz D, Brouwer MC, Van Der Ende A, Van De Beek D. Intracerebral hemorrhages in adults with community associated bacterial meningitis in adults: should we reconsider anticoagulant therapy?. PLoS One. 2012 Sep 13; 7(9):e45271. 
29. Adriani KS, Brouwer MC, Baas F, Zwinderman AH, Van der Ende A, Van de Beek D. Genetic variation in the $\beta 2$-adrenocepter gene is associated with susceptibility to bacterial meningitis in adults. PloS one. 2012 May 18; 7(5):e37618.

30. Weisfelt M, De Gans J, Van Der Ende A, Van De Beek D. Community-acquired bacterial meningitis in alcoholic patients. PLoS One. 2010 Feb 8; 5(2):e9102.

31. Mirecka A. Etiological agents of bacterial meningitis in adults and antibiotic susceptibility of Streptococcus pneumoniae isolated from 2009-2016 from patients of Regional Specialist Hospital of Dr Wł. Biegański in Lódź. Przeglad epidemiologiczny. 2018 Jan 1; $72(3): 313-$ 324.

32. van Veen KE, Brouwer MC, Van Der Ende A, Van De Beek D. Bacterial meningitis in solid organ transplant recipients: a population-based prospective study. Transplant Infectious Disease. 2016 Oct; 18(5):674-680.

33. Gudina EK, Tesfaye M, Wieser A, Pfister HW, Klein M. Outcome of patients with acute bacterial meningitis in a teaching hospital in Ethiopia: A prospective study. PLoS One. 2018 Jul 18; 13(7):e0200067.

\section{Tables}

Table 1: Frequency of study participants by age groups, gender and year at University of Gondar Compressive Specialized Hospital, Gondar, Northwest Ethiopia, 2020. 


\begin{tabular}{|c|c|c|c|c|}
\hline Variables & & & Frequency & Percent \\
\hline \multirow[t]{10}{*}{ Socio-demographic characteristics } & \multirow[t]{6}{*}{ Age group } & $18-27$ & 1199 & $32.6 \%$ \\
\hline & & $28-37$ & 1067 & $29 \%$ \\
\hline & & $38-47$ & 682 & $18.5 \%$ \\
\hline & & $48-57$ & 360 & $9.8 \%$ \\
\hline & & $58-67$ & 214 & $5.8 \%$ \\
\hline & & $\geq 68$ & 161 & $4.4 \%$ \\
\hline & \multirow[t]{2}{*}{ Sex } & Male & 2052 & $55.7 \%$ \\
\hline & & Female & 1631 & $44.3 \%$ \\
\hline & \multirow[t]{2}{*}{ Patient visit } & Inpatient & 3313 & $90 \%$ \\
\hline & & Outpatient & 370 & $10 \%$ \\
\hline \multirow[t]{20}{*}{ Year of data collection } & \multirow[t]{2}{*}{2011} & Male & 224 & $54.8 \%$ \\
\hline & & Female & 185 & $45.2 \%$ \\
\hline & \multirow[t]{2}{*}{2012} & Male & 92 & $46 \%$ \\
\hline & & Female & 108 & $54 \%$ \\
\hline & \multirow[t]{2}{*}{2013} & Male & 203 & $51.5 \%$ \\
\hline & & Female & 191 & $48.5 \%$ \\
\hline & \multirow[t]{2}{*}{2014} & Male & 250 & $57.6 \%$ \\
\hline & & Female & 184 & $42.4 \%$ \\
\hline & \multirow[t]{2}{*}{2015} & Male & 218 & $52.7 \%$ \\
\hline & & Female & 196 & $47.3 \%$ \\
\hline & \multirow[t]{2}{*}{2016} & Male & 184 & $60.7 \%$ \\
\hline & & Female & 119 & $39.3 \%$ \\
\hline & \multirow[t]{2}{*}{2017} & Male & 180 & $55.4 \%$ \\
\hline & & Female & 145 & $44.6 \%$ \\
\hline & \multirow[t]{2}{*}{2018} & Male & 267 & $52.1 \%$ \\
\hline & & Female & 245 & $47.9 \%$ \\
\hline & \multirow[t]{2}{*}{2019} & Male & 272 & $64 \%$ \\
\hline & & Female & 153 & $36 \%$ \\
\hline & \multirow[t]{2}{*}{2020} & Male & 162 & $60.7 \%$ \\
\hline & & Female & 105 & $39.3 \%$ \\
\hline
\end{tabular}

Table 2: Antimicrobial susceptibility profile of gram negative bacterial isolates at University of Gondar specialized hospital, Northwest Ethiopia, from January to August, 2020. 


\begin{tabular}{|c|c|c|c|c|c|c|c|c|c|c|c|c|c|c|}
\hline \multirow[t]{2}{*}{ Antibiotics } & \multicolumn{2}{|l|}{ E. coli } & \multicolumn{2}{|c|}{$\begin{array}{l}N . \\
\text { meningitidis }\end{array}$} & \multicolumn{2}{|c|}{$\begin{array}{l}\text { K. } \\
\text { pneumonia }\end{array}$} & \multicolumn{2}{|c|}{ K. ozanae } & \multicolumn{2}{|c|}{ S. dysenteriae } & \multicolumn{2}{|c|}{$\begin{array}{l}\text { Citrobacter } \\
\text { spss }\end{array}$} & \multicolumn{2}{|c|}{$\begin{array}{l}\text { NLF gram } \\
\text { negative rods }\end{array}$} \\
\hline & $S(\%)$ & $\mathrm{R}(\%)$ & $S(\%)$ & $\mathrm{R}(\%)$ & S (\%) & $\begin{array}{l}\mathrm{R} \\
(\%)\end{array}$ & S (\%) & $\mathrm{R}(\%)$ & $S(\%)$ & $\mathrm{R}(\%)$ & S (\%) & $\mathrm{R}(\%)$ & S (\%) & $\mathrm{R}(\%)$ \\
\hline Ampicillin & $0(0)$ & $\begin{array}{l}5 \\
(100)\end{array}$ & $\begin{array}{l}1 \\
(100)\end{array}$ & $0(0)$ & $\begin{array}{l}1 \\
(50)\end{array}$ & $\begin{array}{l}1 \\
(50)\end{array}$ & $0(0)$ & $\begin{array}{l}3 \\
(100)\end{array}$ & $0(0)$ & $\begin{array}{l}1 \\
(100)\end{array}$ & $\begin{array}{l}1 \\
(100)\end{array}$ & $0(0)$ & $\begin{array}{l}1 \\
(100)\end{array}$ & $0(0)$ \\
\hline Ceftriaxone & $\begin{array}{l}3 \\
(100)\end{array}$ & $0(0)$ & $\begin{array}{l}3 \\
(75)\end{array}$ & $\begin{array}{l}1 \\
(25)\end{array}$ & 2 & $\begin{array}{l}0 \\
(0)\end{array}$ & $0(0)$ & $\begin{array}{l}1 \\
(100)\end{array}$ & $0(0)$ & $\begin{array}{l}1 \\
(100)\end{array}$ & $\begin{array}{l}1 \\
(100)\end{array}$ & $0(0)$ & $1(50)$ & $1(50)$ \\
\hline Chloramphenicol & $\begin{array}{l}2 \\
(50)\end{array}$ & $\begin{array}{l}2 \\
(50)\end{array}$ & $\begin{array}{l}1 \\
(100)\end{array}$ & $0(0)$ & $\begin{array}{l}1 \\
(100)\end{array}$ & $\begin{array}{l}0 \\
(0)\end{array}$ & $\begin{array}{l}1 \\
(100)\end{array}$ & $0(0)$ & N/A & $\mathrm{N} / \mathrm{A}$ & $\begin{array}{l}1 \\
(100)\end{array}$ & $0(0)$ & $\begin{array}{l}1 \\
(100)\end{array}$ & $0(0)$ \\
\hline Ciprofloxacin & $\begin{array}{l}3 \\
(60)\end{array}$ & $\begin{array}{l}2 \\
(40)\end{array}$ & $\begin{array}{l}2 \\
(67)\end{array}$ & $\begin{array}{l}1 \\
(33)\end{array}$ & $\begin{array}{l}3 \\
(75)\end{array}$ & $\begin{array}{l}1 \\
(25)\end{array}$ & $\begin{array}{l}2 \\
(100)\end{array}$ & $0(0)$ & $\begin{array}{l}1 \\
(100)\end{array}$ & $0(0)$ & $\mathrm{N} / \mathrm{A}$ & $\mathrm{N} / \mathrm{A}$ & $\begin{array}{l}2 \\
(66.7)\end{array}$ & $\begin{array}{l}1 \\
(33.3)\end{array}$ \\
\hline Gentamycin & $\begin{array}{l}4 \\
(67)\end{array}$ & $\begin{array}{l}2 \\
(33)\end{array}$ & $0(0)$ & $\stackrel{1}{(100)}$ & $\begin{array}{l}2 \\
(67)\end{array}$ & (33) & $\begin{array}{l}1 \\
(33)\end{array}$ & $\begin{array}{l}2 \\
(67)\end{array}$ & N/A & $\mathrm{N} / \mathrm{A}$ & $\begin{array}{l}1 \\
(100)\end{array}$ & $0(0)$ & $1(50)$ & $1(50)$ \\
\hline Pencilling & $\mathrm{N} / \mathrm{A}$ & $\mathrm{N} / \mathrm{A}$ & $\begin{array}{l}2 \\
(67)\end{array}$ & $\begin{array}{l}1 \\
\text { (33) }\end{array}$ & $\mathrm{N} / \mathrm{A}$ & N/A & $\begin{array}{l}1 \\
(100)\end{array}$ & $0(0)$ & N/A & N/A & $\mathrm{N} / \mathrm{A}$ & $\mathrm{N} / \mathrm{A}$ & N/A & N/A \\
\hline Cotrimoxazole & $\begin{array}{l}3 \\
(100)\end{array}$ & $0(0)$ & $\begin{array}{l}3 \\
(100)\end{array}$ & $0(0)$ & $\begin{array}{l}1 \\
(33)\end{array}$ & $\begin{array}{l}2 \\
(67)\end{array}$ & $0(0)$ & 2 & N/A & N/A & $\begin{array}{l}1 \\
(100)\end{array}$ & $0(0)$ & $1(50)$ & $1(50)$ \\
\hline Amoxicillin & $0(0)$ & $\begin{array}{l}1 \\
(100)\end{array}$ & $\begin{array}{l}3 \\
(100)\end{array}$ & $0(0)$ & $\begin{array}{l}1 \\
(100)\end{array}$ & $\begin{array}{l}0 \\
(0)\end{array}$ & N/A & N/A & N/A & $\mathrm{N} / \mathrm{A}$ & $\begin{array}{l}1 \\
(100)\end{array}$ & $0(0)$ & $\begin{array}{l}1 \\
(100)\end{array}$ & $0(0)$ \\
\hline Norfloxacilin & $0(0)$ & $\begin{array}{l}1 \\
(100)\end{array}$ & 2 & $0(0)$ & $\mathrm{N} / \mathrm{A}$ & N/A & N/A & $\mathrm{N} / \mathrm{A}$ & N/A & $\mathrm{N} / \mathrm{A}$ & $\mathrm{N} / \mathrm{A}$ & $\mathrm{N} / \mathrm{A}$ & N/A & N/A \\
\hline Vancomycin & $\mathrm{N} / \mathrm{A}$ & $\mathrm{N} / \mathrm{A}$ & $\begin{array}{l}1 \\
(100)\end{array}$ & $0(0)$ & $\mathrm{N} / \mathrm{A}$ & N/A & N/A & $\mathrm{N} / \mathrm{A}$ & N/A & $\mathrm{N} / \mathrm{A}$ & $\mathrm{N} / \mathrm{A}$ & $\mathrm{N} / \mathrm{A}$ & N/A & N/A \\
\hline Clindamycin & N/A & $\mathrm{N} / \mathrm{A}$ & $\begin{array}{l}1 \\
(100)\end{array}$ & $0(0)$ & N/A & N/A & $\begin{array}{l}1 \\
(100)\end{array}$ & $0(0)$ & N/A & N/A & $\mathrm{N} / \mathrm{A}$ & $\mathrm{N} / \mathrm{A}$ & N/A & N/A \\
\hline Cefoxtin & $\mathrm{N} / \mathrm{A}$ & $\mathrm{N} / \mathrm{A}$ & $\begin{array}{l}1 \\
(50)\end{array}$ & $\begin{array}{l}1 \\
\text { (50) }\end{array}$ & N/A & N/A & N/A & $\mathrm{N} / \mathrm{A}$ & $0(0)$ & $\begin{array}{l}1 \\
(100)\end{array}$ & $\mathrm{N} / \mathrm{A}$ & N/A & N/A & N/A \\
\hline Meropenem & $\begin{array}{l}1 \\
(100)\end{array}$ & $0(0)$ & $\begin{array}{l}1 \\
(100)\end{array}$ & $0(0)$ & $\begin{array}{l}1 \\
(100)\end{array}$ & $\begin{array}{l}0 \\
(0)\end{array}$ & N/A & $\mathrm{N} / \mathrm{A}$ & N/A & $\mathrm{N} / \mathrm{A}$ & $\mathrm{N} / \mathrm{A}$ & $\mathrm{N} / \mathrm{A}$ & $0(0)$ & $\begin{array}{l}1 \\
(100)\end{array}$ \\
\hline Tetracycline & $\begin{array}{l}3 \\
(100)\end{array}$ & $0(0)$ & $\begin{array}{l}3 \\
(100)\end{array}$ & $\mathrm{N} / \mathrm{A}$ & N/A & $\begin{array}{l}0 \\
(0)\end{array}$ & $\begin{array}{l}2 \\
(100)\end{array}$ & N/A & N/A & N/A & $0(0)$ & $\stackrel{1}{(100)}$ & (100) & $0(0)$ \\
\hline Erythromycin & $\mathrm{N} / \mathrm{A}$ & $\mathrm{N} / \mathrm{A}$ & $\begin{array}{l}3 \\
(100)\end{array}$ & $0(0)$ & N/A & N/A & $\mathrm{N} / \mathrm{A}$ & $\mathrm{N} / \mathrm{A}$ & N/A & $\mathrm{N} / \mathrm{A}$ & $\mathrm{N} / \mathrm{A}$ & $\mathrm{N} / \mathrm{A}$ & N/A & N/A \\
\hline Imipenem & $\mathrm{N} / \mathrm{A}$ & N/A & $\mathrm{N} / \mathrm{A}$ & $\mathrm{N} / \mathrm{A}$ & $\begin{array}{l}1 \\
(100)\end{array}$ & $\begin{array}{l}0 \\
(0)\end{array}$ & N/A & $\mathrm{N} / \mathrm{A}$ & $\begin{array}{l}1 \\
(100)\end{array}$ & $0(0)$ & $\mathrm{N} / \mathrm{A}$ & $\mathrm{N} / \mathrm{A}$ & N/A & N/A \\
\hline Cefuroxime & $\mathrm{N} / \mathrm{A}$ & $\mathrm{N} / \mathrm{A}$ & $\mathrm{N} / \mathrm{A}$ & $\mathrm{N} / \mathrm{A}$ & $\begin{array}{l}1 \\
(100)\end{array}$ & $\begin{array}{l}0 \\
(0)\end{array}$ & $0(0)$ & $\begin{array}{l}1 \\
(100)\end{array}$ & $0(0)$ & $\begin{array}{l}1 \\
(100)\end{array}$ & $\mathrm{N} / \mathrm{A}$ & $\mathrm{N} / \mathrm{A}$ & $0(0)$ & $\begin{array}{l}1 \\
(100)\end{array}$ \\
\hline Tobramycin & $\mathrm{N} / \mathrm{A}$ & N/A & $\mathrm{N} / \mathrm{A}$ & N/A & N/A & N/A & $0(0)$ & $\begin{array}{l}1 \\
(100)\end{array}$ & N/A & $\mathrm{N} / \mathrm{A}$ & $\mathrm{N} / \mathrm{A}$ & $\mathrm{N} / \mathrm{A}$ & $0(0)$ & $\begin{array}{l}1 \\
(100)\end{array}$ \\
\hline Ceftazidime & $\mathrm{N} / \mathrm{A}$ & N/A & $\mathrm{N} / \mathrm{A}$ & $\mathrm{N} / \mathrm{A}$ & $\begin{array}{l}2 \\
(100)\end{array}$ & $\begin{array}{l}0 \\
(0)\end{array}$ & N/A & $\mathrm{N} / \mathrm{A}$ & N/A & $\mathrm{N} / \mathrm{A}$ & N/A & $\mathrm{N} / \mathrm{A}$ & $0(0)$ & $\begin{array}{l}1 \\
(100)\end{array}$ \\
\hline
\end{tabular}

$\mathrm{S}=$ Sensitive, $\mathrm{R}=$ Resistant, NLF = Non Lactose Fermenter, N/A = Not Applicable

Table 3: Antimicrobial susceptibility profile of gram positive bacterial isolates at University of Gondar specialized hospital, Northwest Ethiopia, from January to August, 2020. 


\begin{tabular}{|c|c|c|c|c|c|c|c|c|c|c|}
\hline \multirow[t]{2}{*}{ Antibiotics } & \multicolumn{2}{|c|}{$\begin{array}{l}\text { Streptococcus } \\
\text { pneumoniae }\end{array}$} & \multicolumn{2}{|c|}{$\begin{array}{l}\text { Streptococcus } \\
\text { viridians }\end{array}$} & \multicolumn{2}{|c|}{$\begin{array}{l}\text { Staphylococcus } \\
\text { aureus }\end{array}$} & \multicolumn{2}{|c|}{$\begin{array}{l}\text { Coagulase negative } \\
\text { staphylococci }\end{array}$} & \multicolumn{2}{|c|}{$\begin{array}{l}\text { Listeria } \\
\text { monocytogenes }\end{array}$} \\
\hline & S (\%) & $\mathrm{R}(\%)$ & S (\%) & $\mathrm{R}(\%)$ & $\mathrm{S}(\%)$ & $\mathrm{R}(\%)$ & S (\%) & $\mathrm{R}(\%)$ & $\mathrm{S}(\%)$ & $\mathrm{R}(\%)$ \\
\hline Ampicillin & $6(100)$ & $0(0)$ & $\mathrm{N} / \mathrm{A}$ & $\mathrm{N} / \mathrm{A}$ & $\begin{array}{l}1 \\
(33.3)\end{array}$ & $\begin{array}{l}2 \\
(66.7)\end{array}$ & $\mathrm{N} / \mathrm{A}$ & $\mathrm{N} / \mathrm{A}$ & $1(100)$ & $0(0)$ \\
\hline Ceftriaxone & $6(100)$ & $0(0)$ & $\mathrm{N} / \mathrm{A}$ & $\mathrm{N} / \mathrm{A}$ & $3(100)$ & $0(0)$ & $1(100)$ & $0(0)$ & $1(100)$ & $0(0)$ \\
\hline Chloramphenicol & 7 (77.8) & $2(22.2)$ & $0(0)$ & $1(100)$ & $0(0)$ & $1(100)$ & $\mathrm{N} / \mathrm{A}$ & $\mathrm{N} / \mathrm{A}$ & $1(100)$ & $0(0)$ \\
\hline Ciprofloxacin & 5 (83.3) & $1(16.7)$ & $\mathrm{N} / \mathrm{A}$ & $\mathrm{N} / \mathrm{A}$ & $\begin{array}{l}2 \\
(66.7)\end{array}$ & $\begin{array}{l}1 \\
(33.3)\end{array}$ & $\mathrm{N} / \mathrm{A}$ & $\mathrm{N} / \mathrm{A}$ & $\mathrm{N} / \mathrm{A}$ & N/A \\
\hline Gentamycin & $1(25)$ & $3(75)$ & $0(0)$ & $1(100)$ & N/A & $\mathrm{N} / \mathrm{A}$ & $\mathrm{N} / \mathrm{A}$ & $\mathrm{N} / \mathrm{A}$ & $1(100)$ & $0(0)$ \\
\hline Pencilling & $11(100)$ & $0(0)$ & $0(0)$ & $1(100)$ & $1(50)$ & $1(50)$ & $1(100)$ & $0(0)$ & $\mathrm{N} / \mathrm{A}$ & N/A \\
\hline Cotrimoxazole & $2(33.3)$ & $4(66.7)$ & N/A & $\mathrm{N} / \mathrm{A}$ & $0(0)$ & $3(100)$ & $1(100)$ & $0(0)$ & $\mathrm{N} / \mathrm{A}$ & N/A \\
\hline Amoxicillin & $3(100)$ & $0(0)$ & $\mathrm{N} / \mathrm{A}$ & $\mathrm{N} / \mathrm{A}$ & $\begin{array}{l}2 \\
(66.7)\end{array}$ & $\begin{array}{l}1 \\
(33.3)\end{array}$ & $\mathrm{N} / \mathrm{A}$ & $\mathrm{N} / \mathrm{A}$ & $1(100)$ & $0(0)$ \\
\hline Norfloxacilin & $3(100)$ & $0(0)$ & $\mathrm{N} / \mathrm{A}$ & $\mathrm{N} / \mathrm{A}$ & $1(100)$ & $0(0)$ & $\mathrm{N} / \mathrm{A}$ & $\mathrm{N} / \mathrm{A}$ & $\mathrm{N} / \mathrm{A}$ & N/A \\
\hline Vancomycin & 7 (87.5) & $1(12.5)$ & $1(100)$ & $0(0)$ & $\begin{array}{l}2 \\
(66.7)\end{array}$ & $\begin{array}{l}1 \\
(33.3)\end{array}$ & $1(100)$ & $0(0)$ & $1(100)$ & $0(0)$ \\
\hline Clindamycin & N/A & N/A & $\mathrm{N} / \mathrm{A}$ & $\mathrm{N} / \mathrm{A}$ & $3(100)$ & $0(0)$ & $\mathrm{N} / \mathrm{A}$ & $\mathrm{N} / \mathrm{A}$ & $1(100)$ & $0(0)$ \\
\hline Cefoxtin & $2(100)$ & $0(0)$ & $\mathrm{N} / \mathrm{A}$ & $\mathrm{N} / \mathrm{A}$ & $3(100)$ & $0(0)$ & $\mathrm{N} / \mathrm{A}$ & $\mathrm{N} / \mathrm{A}$ & $\mathrm{N} / \mathrm{A}$ & N/A \\
\hline Tetracycline & $3(42.9)$ & $4(57.1)$ & $\mathrm{N} / \mathrm{A}$ & $\mathrm{N} / \mathrm{A}$ & $\begin{array}{l}1 \\
(33.3)\end{array}$ & $\begin{array}{l}2 \\
(66.7)\end{array}$ & $0(0)$ & $1(100)$ & $\mathrm{N} / \mathrm{A}$ & N/A \\
\hline Erythromycin & $4(80)$ & $1(20)$ & $\mathrm{N} / \mathrm{A}$ & $\mathrm{N} / \mathrm{A}$ & $\begin{array}{l}4 \\
(66.7)\end{array}$ & $\begin{array}{l}2 \\
(33.3)\end{array}$ & $0(0)$ & $1(100)$ & $\mathrm{N} / \mathrm{A}$ & N/A \\
\hline Cefuroxime & $1(100)$ & $0(0)$ & $\mathrm{N} / \mathrm{A}$ & N/A & N/A & $\mathrm{N} / \mathrm{A}$ & $\mathrm{N} / \mathrm{A}$ & $\mathrm{N} / \mathrm{A}$ & N/A & N/A \\
\hline Kanamycin & $1(100)$ & $0(0)$ & $\mathrm{N} / \mathrm{A}$ & $\mathrm{N} / \mathrm{A}$ & $\mathrm{N} / \mathrm{A}$ & $N / A$ & N/A & N/A & $1(100)$ & N/A \\
\hline
\end{tabular}

$\mathrm{S}=$ Sensitive, $\mathrm{R}=$ Resistant, $\mathrm{NLF}=$ Non Lactose Fermenter, $\mathrm{N} / \mathrm{A}=$ Not Applicable

Figures 


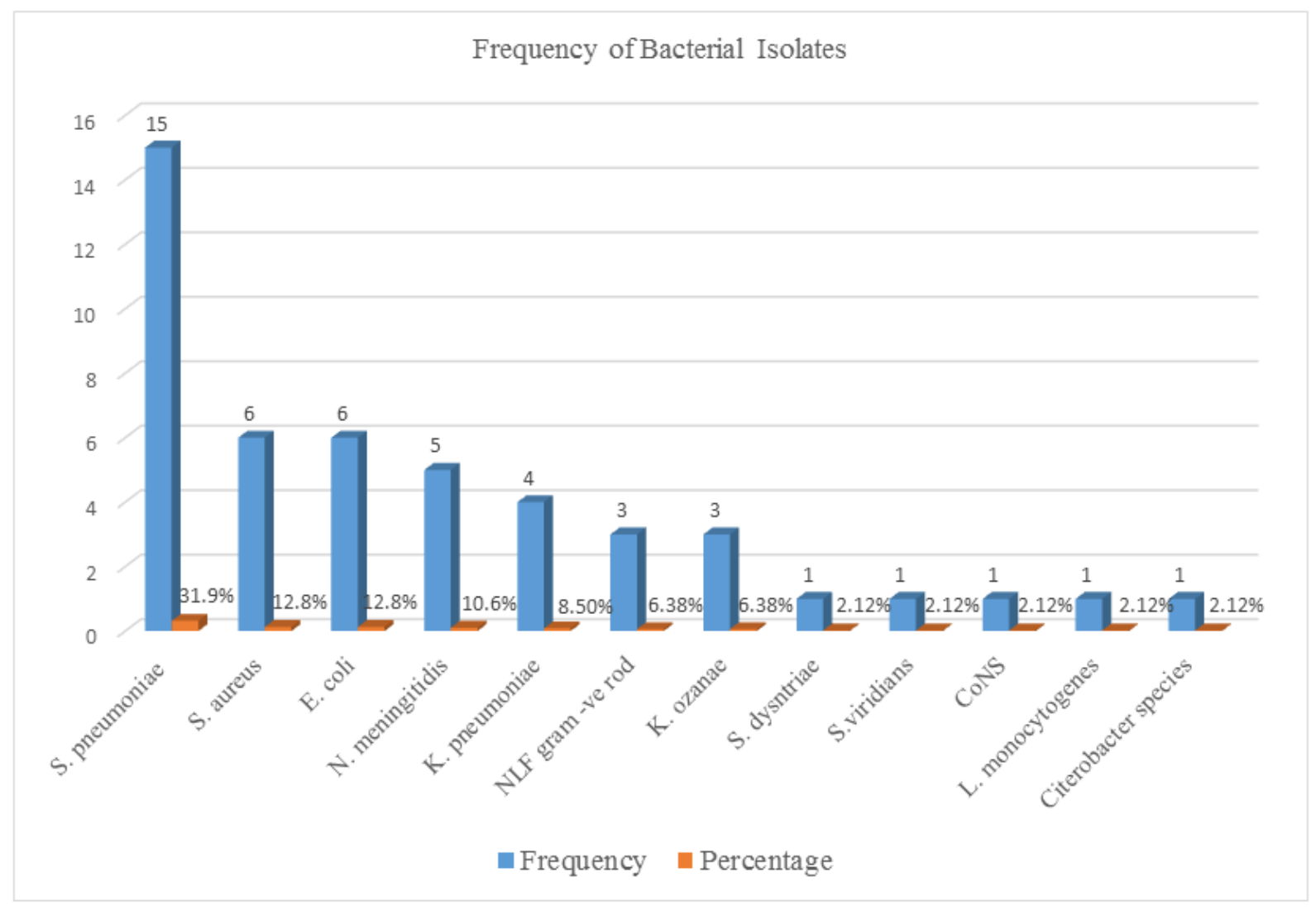

\section{Figure 1}

Frequency and percentage of bacterial isolates at University of Gondar Compressive Specialized Hospital, Gondar, Northwest Ethiopia, 2020.

\section{Trends of bacterial meningitis by years}

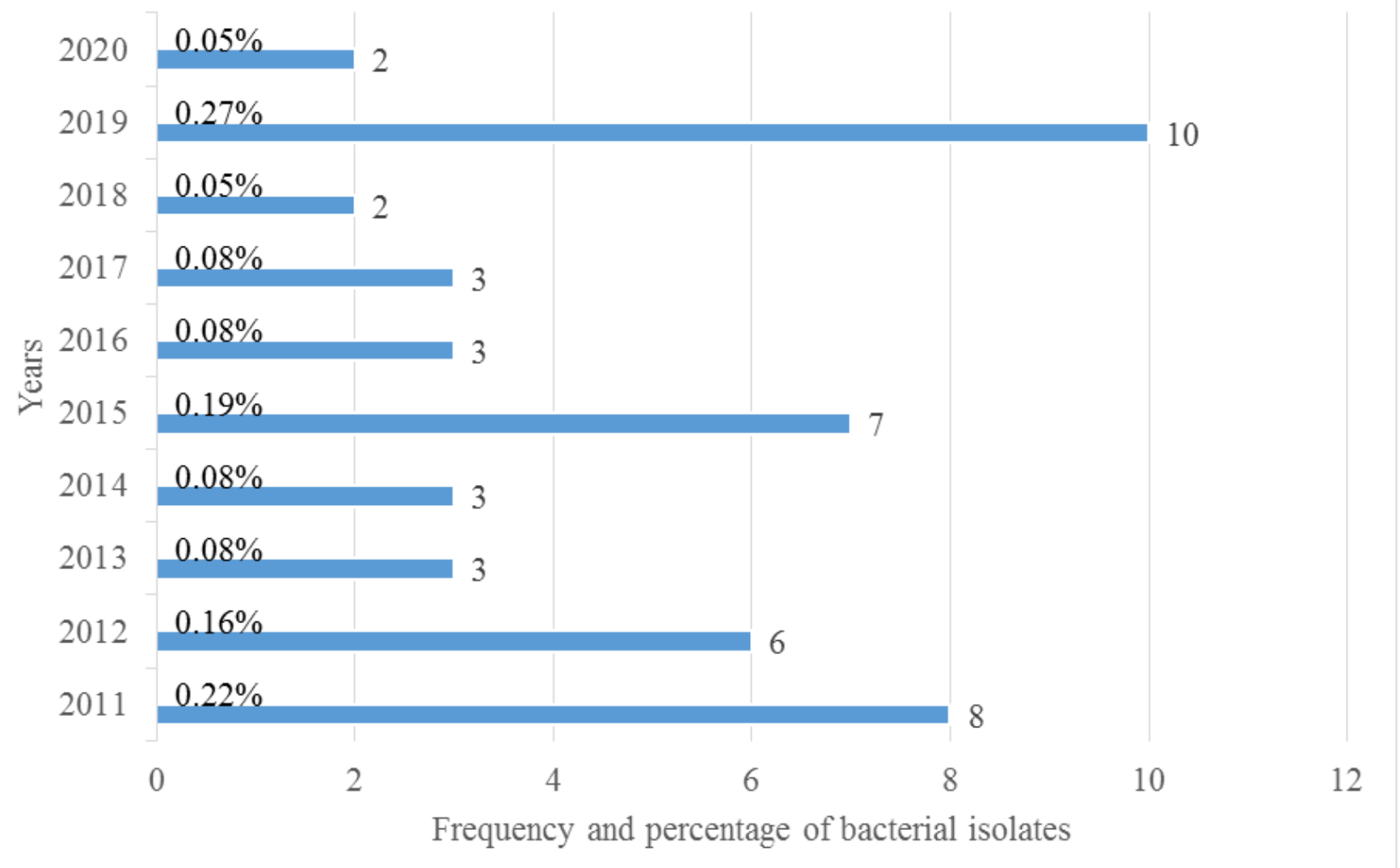

Page $11 / 12$ 
Figure 2

Trends of bacterial meningitis by years at University of Gondar Compressive Specialized Hospital, Gondar, Northwest Ethiopia, 2020. 